\title{
Foreign student's adaptation management, assessment and forecasting algorithms and software
}

\author{
Sergey Romanchukov \\ National Research Tomsk Polytechnic University \\ Tomsk, Russia \\ inoy@vtomske.ru \\ Olga Berestneva \\ National Research Tomsk Polytechnic University \\ Tomsk, Russia \\ ogb6@yandex.ru
}

\author{
Oksana Fisochenko \\ National Reseaı \\ Tomsk, Russia \\ giri@rambler.ru \\ echnic University \\ Konstantin Sharopin \\ National Research Tomsk Polytechnic University \\ Tomsk, Russia \\ line 4-e-mail address if desired
}

\begin{abstract}
The modern educational system faces a number of exchange student's adaptation problems. It is necessary to determine the optimal solution for foreign student's adaptation assessment, prediction and management, to form an indicator system for adaptation process prognostic and risk reducing models. This paper is devoted to the integrated approach development of mathematical algorithms and software for monitoring, evaluating and managing the foreign student's adaptation process in the Russian universities. Methods of multivariate statistical analysis, fuzzy sets, data mining and the hierarchy analysis method were used in the study. An integrated approach to risk management was implemented to propose a criteria for the foreign student's adaptation abilities assessment (via the fuzzy sets method), and hierarchical risk model's design. The fuzzy sets method's application for the foreign student's adaptation level diagnostics in Russian universities makes it possible to successfully assess the adaptation level for any set of initial characteristics. The application of a heterogeneous sequential procedure allows to forecast the foreign student's adaptation development and disruption. The hierarchy analysis method allowed data structuring for setting decision priorities. An integrated approach for the foreign student's adaptation assessment, prediction and management was implemented. A set of methods was developed to assess the level of exchange student's individual adaptation to the university studying or its breakdown, decisive rules for the level of adaptation prediction were obtained. A decision support system has been developed for foreign student's adaptation process management.
\end{abstract}

Keywords - exchange students, adaptation, disadaptation, evaluation, prediction

\section{INTRODUCTION}

For the modern university, the international activity is ground for its sustainability and success. Today, the Russian universities have an ambitious task: to enter the international educational space and firmly establish themselves in it. The number of foreign students can serve as one of the indicators of the university's success in the international market of educational services. So, international education, doubledegree programs and academic exchange are actively involved in the process of educational system's export, which has resulted in the coherence of curricula and learning procedures, but with respect to uniqueness of the specific country's traditions and culture. Accordingly, there has been a growing demand for research on the problems of foreign student's adaptation.

Exchange students are interested in the rapid adaptation to new conditions and adjustment of the ties that are familiar in their previous life in all the main spheres (in everyday life, pastime, studies, etc). Successful adaptation facilitates the rapid entry of students into the learning process and ultimately influences the outlook for contingent preservation and final results of the educational process. The presence of multiple factors acting on the adaptation process at the same time can result in a large number of troubles, and it is difficult for an exchange student to deal with all of them without any help. At the stage of entering the unusual conditions of life and learning process, it is extremely important to get attention, understanding and condescension to the arising problems from the university staff. In view of the above, the university should take into account foreign student's individual and socio-cultural characteristics during the learning process organization and provide necessary help in the period of their adaptation to the new educational environment.

Problems of exchange student's adaptation are relevant for higher education institutions in all regions of Russia. The research presented in this paper was conducted mostly on the basis of the National Research Tomsk Polytechnic University.

Studies on the foreign student's adaptation problems have been held in TPU for over 10 years. The identified problems and possible approaches to their solution are presented in a number of works $[1,2,3,4]$. However, most of them consider only certain aspects of this problem, while in general, it is necessary to create and implement in the decision management process (in the field of adaptation) a comprehensive program that will ensure the high quality of education and allow foreign students to achieve the best academic results with the least negative consequences. 


\section{Problem Statement}

One of the directions of the administrative work of the university's international service is management of the exchange student's adaptation process. Optimizing the interaction of this social group with the educational environment conditions, which is the goal of managing the process of social adaptation, is now acquiring special significance in connection with the expansion of the foreign student's contingent in Russian universities [5].

Significant part of the foreign students who came to study in Russia leave back home for the first two years, facing with various difficulties. The need to manage this process is important because the overall development of the entire educational system for foreign specialists depends on results of adaptation activities. One of the features of the adaptation process is that students them self acts both as an object and as a subject of the given process $[6,7]$.

Therefore, the work on the organization of proper conditions includes several main stages. First of all, it is necessary to carefully study the main features and factors affecting the adaptation of foreign students. The most difficult and largely determining stage in the exchange student's adaptation is the first year of their stay at the university.

Acquiring skills and behaviors for actions in certain everyday situations is decisive for adapting a person to a foreign culture. Skills and abilities are divided into technical (language skills, shopping skills, etc.) and social skills, which are much more difficult to master. Nevertheless human behavior is constantly improved (on the example of student's own and others' mistakes) and finally organized into algorithms and stereotypes, which can then be used automatically.

In the behavioral aspect, special attention is paid to communicative adaptation in terms of personal and social communication $[7,8]$.

Communicative adaptation begins to manifest, literally, from the first steps on Russian soil. Unsuccessful communication with a representative of another culture causes disappointment. However, a person often does not understand that the source of these feelings is his own inability to communicate adequately. Three interrelated aspects can be distinguished in communicative adaptation: cognitive, affective and behavioral.

Personal communication is closely connected with social, which manifests itself in various forms from simple observation of people in public places or reading press materials and to personal contacts with friends.

Social communication is usually divided into interpersonal and mass one, which consists in the interaction of the individual and his sociocultural environment without direct contact with individual people. The more experience an individual acquires in the sphere of social communication, the better he adapts to another's culture. To this end, it is necessary to have more interpersonal contacts with native speakers and culture, actively use the media [6,7].

Speaking about social adaptation, it is necessary to pay attention to the tasks facing the faculties:
- exchange student's social adaptation in a different socio-cultural environment;

- exchange student's psychological adaptation to the educational space of the university, the new living conditions, the student team;

- rendering assistance in physiological adaptation of foreign students;

- $\quad$ rendering of the individual help to foreign students in the decision of various questions;

- $\quad$ specially organized socio-pedagogical conditions in which the inclusion of representatives of other cultures in the process of intercultural interaction;

- pedagogical activity aimed at the formation of professional educational values;

- pedagogical activity aimed at the foreign student's adequate perception of the Russian language and cultural values.

The curatorship institution is the cornerstone in the adaptation process management. In order to understand the importance of social and educational work with foreign students it is necessary to present the whole complex of problems faced by foreign students arriving in our country. This problems are:

1. Language barrier. In the initial period foreigners have less opportunities to ask questions or state their problems.

2. Cultural barrier. Relations with native speakers and culture will not be adequate if the individual can not share his or her feelings with them. When a person achieves the necessary level of adaptation it allows to demonstrate both positive and negative emotions in communication with representatives of the indigenous culture.

3. Unfamiliar climatic conditions. Some exchange students in Russia are completely unprepared for living in colder climates.

4. Lack of self-sufficiency. So, the living conditions differ sharply from those to which foreign students were accustomed at home (in the best or worst for the various students side). Exchange student need to solve a whole range of various problems: medical treatment, economic and security issues, registration of necessary documents for migration accounting, etc.

And in this case the curator can provide invaluable assistance [6,7] for newcomers. However, the tasks of adaptation process management, its diagnosis and information support acquire special significance for effective work of the curator.

\section{RESEARCH QUESTIONS}

The main purpose of the adaptation management is to eliminate the causes which can increase maladaptation risks. The effective management technology presupposes the compilation of an appropriate algorithm, the balanced set of methods and techniques for influencing the adaptation process 
and set of both qualitative and quantitative indicators for adaptation process monitoring.

In the process of the exchange student's maladaptation risks management we take 3 main stages of the risk management process (the process of making and executing management decisions aimed at reducing the likelihood of an adverse result and minimizing possible losses):

1. Identification and selection of factors that have the greatest impact on adaptation process disruption;

\section{Assessment of factors, which affects maladaptation risks;}

\section{Reducing the risk of maladaptation.}

We formulate the requirements for an integrated system for assessing, forecasting and managing the foreign student's adaptation during 3 main stages:

On the first stage it is necessary to determine the basic composition of indicators that assess all aspects of the foreign student's adaptation, to find out factors with negative impact, which can lead to maladaptation. At this stage it is necessary to select a set of techniques that are able to assess the level of individual adaptation, with respect to existing literature sources and expert opinions. Since adaptation is a complex, multilevel process, there is a large number of different evaluation methods. But it is necessary also to cut dimension of the indicative space in order to reduce the complexity of decisionmaking process in risk management, so the resulting set of techniques should be also reduced.

The selection of methodologies will be based on two criteria:

1) the informative value of the indicators evaluated by selected methodologies;

2) low laboriousness (which means that express methods are preferable).

On the second stage (after the indicator's selection) it is necessary to evaluate obtained indicators and then use them to predict the development of foreign student's adaptive behavior. We are faced with the task of assessing the level of adaptation both in a complex and at different levels of adaptation, such as psychological, social, psycho-physiological, as well as assessing the adaptive potential. Another task is to predict the change in the level of adaptation and is also to identify factors contributing to the maladaptation of exchange students.

On the third stage it is necessary to suggest possible ways of correcting the obtained indicators according to results of their implementation.

\section{Purpose OF THE STUdy}

The purpose of the work is to select methods for reducing the risk of exchange student's maladaptation. It is necessary to analyze the activities with foreign students conducted in Russian universities, which will highlight the main areas of work with foreign students, which will reduce the risk of maladaptation. It is necessary to build a model which will solve the problem of choosing the optimal maladaptation risks management strategies and will assess their effectiveness.

\section{RESEARCH MethodS}

In general, adaptation is a complex, multilevel process and adaptation management is a comprehensive program that provides education quality for international students in order to achieve the best academic results with the least negative consequences [9].

At the current stage of the Russian educational services market development, there is no integrated approach that takes into account all aspects of the assessment, forecasting and management of the adaptation of foreign students. The drawback of existing approaches is their narrow focus, descriptive character and the lack of adaptation management models. Taking into account the above-mentioned aspects, the structure of an integrated approach to the exchange student's adaptation management was developed as it shown on the Fig.1.

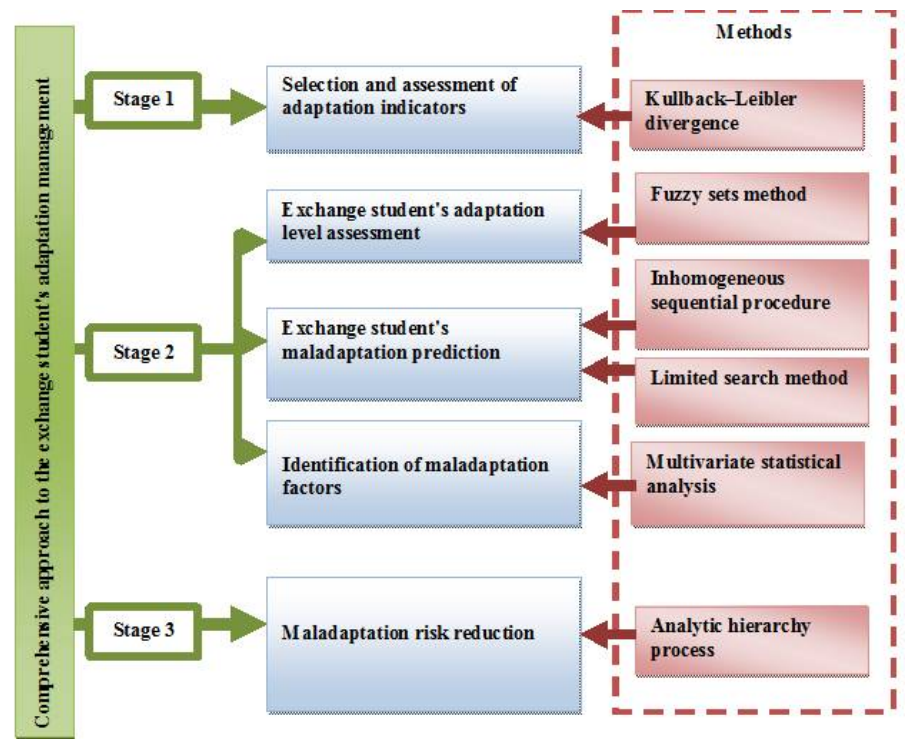

Fig. 1. Adaptation management integrated approach

\section{A. Selection and assessment of adaptation indicators}

Due to the difficulty of testing a large number of exchange students, the set of methods was reduced. Initially, there is a significant number of techniques for testing TPU student's psychological indicators (diagnosis of self-assessment by Spielberg and Khanina, differential diagnosis of depressive states, G. Eysenck diagnosis of psychological self-assessment, the Giessen questionnaire, "subjective control level", "victim behavior addiction" questionnaire, ITO LN"Sobchik methodology, SF-36 questionnaire, S. Maddy's test of resilience, Toronto alexithymic scale, OFDSI by Rusalova, morphological test of life values, Freiburg personal questionnaire, quality of life questionnaire (WHOQOL-100), "value"and "accessibility" correlation level in various life spheres" by Fantalova, etc) [10].

Information was evaluated on the basis of Kulbak's information metric [11,12]. To measure the amount of information, V.Viner and K.Shannon proposed logarithmic metrics that were recognized as quantitative measures of information back in 1948 independently of each other. 
To assess the informativeness of the characteristics, it was necessary to break the values of each feature into several ranges. Those ranges were taken from the literature description of the implemented test procedures. The full list of techniques includes 97 indicators for evaluation. An analysis of the obtained values showed that the majority of the indicators are informative for assessing the adaptation process, but their effectiveness differs significantly. The characteristics with the most informative values are (from different testing techniques): Control; The index of general adaptability; Mental health; Professional life; Stiffness; Personal anxiety; Financially secured life; Family life; Index of discrepancy "Value-Availability" (R); Achievements; Pressure; Depression level; Happy family life; SpontaneityQuality of life; Anxiety; Self-confidence; Involvement; Rheumatic factor; Hobbies.

At this stage, the indicative space is reduced, which will reduce the complexity of decision-making in future maladaptation risk management.

And it is important, that a set of methods, which allows to calculate selected indicators, covers all main types of adaptation.

1. Psychological adaptation: Diagnosis of self-assessment by Ch. D. Spielberg, Yu. L. Khanina; G. Eisenk's test; Differential diagnosis of depressive states; Methodology of ITO LN Sobchik; OFDSI by Rusalova.

2. Psychophysiological adaptation: the Giessen questionnaire; SF-36 questionnaire.

3. Social adaptation: Morphological test of life values; Quality of Life Questionnaire (OCRQ-100); Test of hardiness by S.Maddi, Test methodology by E.B. Fantalova.

4. Adaptation potential: The "Forecast" methodology, developed in the LMMA named after. S. Kirov.

These tests satisfy all the necessary requirements for psychodiagnostic procedures, therefore they were chosen to solve the problem of assessing the TPU exchange students adaptation parameters. At this stage, the basic composition of the indicators for adaptation level assessment was determined. This set of informative signs also coincided with the most informative indicators revealed using WizWhy technology on the same dataset.

\section{B. Adaptation level integral indicator}

At the first stage, the values of each indicator were divided into several ranges. This ranges are compiled on the basis of well-known literature sources [13, 14]. Diagnostic coefficients were obtained for the entire set of characteristics in order to construct a decision rule based on the inhomogeneous sequential procedure method. The object of classification is the exchange student's adaptation level [15].

A three-level states classifier with trapezoid membership functions was used. An example of the membership function for the "anxiety" indicator is shown in Fig. 2. Similar classifiers were constructed for all selected parameters.

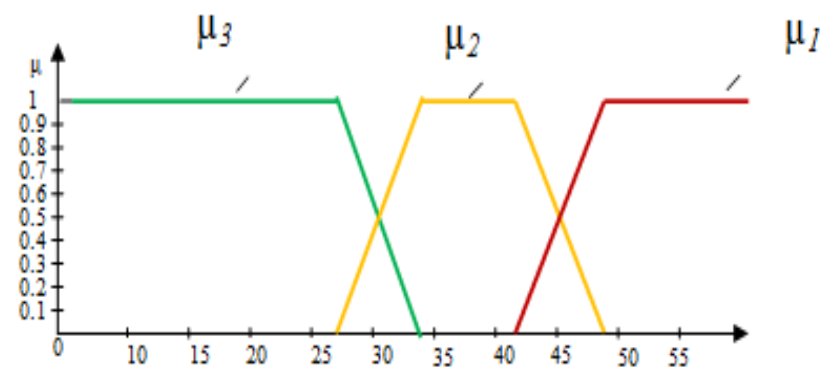

Fig. 2. Membership function for the "anxiety" indicator

The classifier of the adaptation level is represented by the following functions:

$\mu 1(\mathrm{x})$ - for an unsatisfactory level of adaptation (disadaptation);

$\mu 2(\mathrm{x})$ - for a satisfactory level of adaptation;

$\mu 3(\mathrm{x})$ - for a good level of adaptation.

Levels of adaptation of foreign students [16]:

- A good level of adaptation is a positive attitude towards learning, an adequate response to the professor's demands, a deep and complete assimilation of the material, a favorable social status in the team.

- Satisfactory level of adaptation means a positive attitude towards the university (training does not cause negative emotions), understanding and assimilation of educational material with minor negative effects.

- An unsatisfactory level of adaptation is the predominance of negative mood, complaints about health, the need for constant external control, the lack of friendly communication in the student's group. This level corresponds to unsuccessful adaptation (maladaptation).

The measure of the student's adaptation parameters level belonging $\mathrm{P}(\mathrm{Ki})$ to the $\mathrm{i}$-th class is determined by summing $\mu \mathrm{i}(\mathrm{x})$ for each of the indicators.

Since the functions $\mu 1(\mathrm{x})-\mu 3(\mathrm{x})$ are complementary, the following equality holds: $\mathrm{P}(\mathrm{K} 1)+\mathrm{P}(\mathrm{K} 2)+\mathrm{P}(\mathrm{K} 3)=1$

The indicator $\mathrm{K} *$ is an integral indicator for assessing the level of adaptation of foreign students. It is stated as maximum between $\mathrm{Ki}$.

$$
\mathrm{K}^{*}=\arg (\max \{\mathrm{P}(\mathrm{K} 1), \mathrm{P}(\mathrm{K} 2), \mathrm{P}(\mathrm{K} 3)\})
$$

The proposed algorithm allows to successfully evaluate the level of adaptation of students for any set of initial characteristics.

\section{Exchange student's adaptation assessing and forecasting software}

The software for the exchange student's adaptation assessing and forecasting was developed as the Bayesian decision support system, based on the above considerations. 
Functions of the developed information system are:

1. Testing and questioning;

2. Adaptation level assessment;

3. Adaptation level forecasting;

4. Student's professional guidance;

5. Adaptation potential assessment (based on integrated indicators);

6. Risk group definition;

7. Generalized report and recommendations.

Let's consider each function more detailed:

\section{Testing and questioning.}

Input information: student's answers to test questions and questionnaires.

Output information: results of testing and questioning; report on the results.

Testing of foreign students is based on a set of methods that can assess the level of individual adaptation, which were named in section 5A. At the stages of assessing the indicator's informativeness, it was revealed that the quality of recognition with few methods and only 20 indicators is no worse than the recognition by a full set of techniques having high informative indicators.

\section{Adaptation level assessment.}

Input information: results of testing and questioning.

Output: value of the integral adaptation level indicator; report on the student's psycho-physiological adaptation; report on the student's psychological adaptation; report on the student's social adaptation.

This function makes it possible to evaluate various types of adaptation (psychophysiological, psychological, social, adaptive potential) on the basis of informative indicators, and selected psychological methods, both in a complex and separately. Assessment of the adaptation level is done by the method of fuzzy sets, taking into account the membership functions constructed according to informative indicators. The estimated indicator is an integral indicator for the adaptation level assessment.

\section{Adaptation level forecasting.}

Input information: results of testing and questioning.

Output: adaptation level forecast.

This function allows to forecast the development of adaptation opportunities for foreign students. Decisive rules for predicting the adaptation level based of the SPE can accurately predict the class of adaptivity assigned to the student.

\section{Student's professional guidance.}

Input information: results of testing and questioning; data on the educational programs.
Imprint: report on professional inclinations and recommended directions.

This function allows to assess the professional inclinations of students. The evaluation is carried out using the vocational orientation model constructed by the author [17] on the basis of discriminant analysis. Based on the assessment, recommendations are given on the choice of the educational program at the university. The right choice of a profession by students according to their abilities and interest in the specialty being mastered helps to prevent a decrease in the adaptation level.

5. Adaptation potential assessment (based on integrated indicators).

Input information: adaptation level forecast.

Output information: values of the adaptation potential integrated indicators.

This function allows to assess the adaptation potential of foreign students. The evaluation is performed using the integrated indicators constructed in the framework of this study.

\section{Risk group definition.}

Input information: results of adaptation level forecasting; the values of the adaptation potential integrated indicators; expert assessments.

Output information: data on students at risk.

Based on the results of forecasting and the values of integrated indicators, as well as expert assessments, this function forms a risk group, which includes foreign students prone to maladaptation in the process of studying at the university.

7. Formation of a generalized report and recommendations on the results of testing.

Input information: the results of the adaptation level assessment, the value of the integral indicator; results of adaptation level forecasting; values of integrated indicators of the adaptation potential; data on students who are at risk of maladaptation.

Output information: risk group report; conclusion on the results of the student's adaptation forecast and adaptation potential; conclusion on the level of adaptation of foreign students; recommendations for group curators, psychologists of faculties.

The expert, based on the information received about the current state of adaptation of foreign students and their adaptive capabilities, can plan the process of correcting the current state of foreign students with pronounced signs of disadaptation.

The developed software allows to conduct repeated monitoring, to evaluate the results of corrective measures.

The decision-maker can use any stage independently of each other, or the whole system as a whole. In general, the software "Assessment and forecasting of the adaptation of 
foreign students" can be used both in the period of admission, during the period of study at the preparatory faculty, and directly at all stages of training for foreign students.

\section{FINDINGS}

This software was used when working with foreign students in IC TPU (in particular with Vietnamese exchange students). The results of its application, in general, coincided with the results obtained by the international TPU service with the use of other (traditional) methods, in assessing the effectiveness of various so-called. "scenarios" and support programs.

An analysis of the alternative scenarios evaluation results showed that the social level of adaptation is most effectively influenced by socio-cultural activities and, to a lesser extent, vocational guidance and pre-university training of foreign applicants.

The psychological level of adaptation is most affected by scenarios of social and cultural activities and tutoring.

At the psychophysiological level the vocational guidance, pre-university training of foreign applicants and socio-cultural activities are most influential. Analysis of generalized outcome's integral assessments showed the implementation of goals aimed at improving the social and psychophysiological levels of adaptation has the greatest impact on the maladaptation risk reduction. Logical conclusions, however, one can not but note the great convenience of the new methodology and the reduction of labor costs.

\section{CONCLUSION}

The main advantages of the proposed integrated approach:

- it provides a mechanism for adaptation indicators selection and ranking, contributing to the reduction of the characteristic space;

- calculation and assessment of significant indicators (on psychophysiological, psychological, social levels and adaptation potential) takes into account the specifics of data assessed by psychodiagnostic testing methods, questionnaires, expert evaluation and expressed in odd terms;

- it allows calculation of the generalized exchange student's adaptation level assessment;

- it can be used for prediction of adaptation disruption, by a method suitable for all forms of distribution, which can be also attributed to non-parametric ones;

- integrated criteria can be used for comparing different adaptation strategies or scenarios;

- modules can be used at any stage independently or as a whole system.

The application of Kulbak's information measure made it possible to reduce the indicative space of markers that depicts the exchange student's adaptation level from 97 to 20 most informative.

The software "Assessment and forecasting of adaptation of foreign students" can be applied in the work of educational institutions that have foreign students as part of the students, as well as enterprises that have foreign workers as part of the workforce.

Research materials are introduced and used in the educational process at the Tomsk Polytechnic University (Institute of Cybernetics and the Yurginsk Institute of Technology); Moscow Humanitarian and Economic University, as well as in the organization of work with foreign students of TPU, SibGMU, TSPU and Moscow University of Humanities and Economics."

\section{ACKNOWLEDGMENT}

The research is carried out at Tomsk Polytechnic University within the framework of Tomsk Polytechnic University Competitiveness Enhancement Program grant.

\section{REFERENCES}

[1] O. Berestneva, K. Sharopin, "Postroenie modelej adaptacii studentov k obucheniyu v vuze" ["Models of students' adaptation to learning in high school"], Tidings of Tomsk Polytechnic University, Tomsk, 2004, Vol 5, pp. 131-135.

[2] O. Berestneva, O. Maruhina, E. Mokina, "Rol' lichnostnoorientirovannoj sredy vuza $\mathrm{v}$ socialno-psihologicheskoj adaptacii inostrannyh studentov" ["The role of the person-oriented environment of the university in the socio-psychological adaptation of foreign students"], Internet-Journal of Science, 2013, Vol. 4, [Electronic resource] Access mode: http://naukovedenie.ru/PDF/31pvn413.pdf

[3] Y. Kirilova, "Kulturno-massovaya deyatelnost kak odin iz vazhnyh sposobov adaptacii inostrannyh studentov $\mathrm{V}$ tomskom politekhnicheskom universitete" ["Mass cultural activity as one of the important ways of foreign student's adaptation in Tomsk Polytechnic University"], International Journal of Applied and Fundamental Research, Penza: Publishing House "Academy of Natural History", 2015, Vol. 5-4, pp. 670-672

[4] E. Kosheleva, "Vliyanie faktorov stressa na adaptaciyu $k$ akademicheskomu processu v rossijskom vuze inostrannyh i rossijskih studentov" ["The influence of stress factors on foreign and Russian student's adaptation to the academic process in a Russian university"], Almanac of modern science and education, 2015, Vol. 4, pp. 95-98

[5] E. Stepanenko "Upravlenie socialnoj adaptaciej inostrannyh studentov v rossijskom tekhnicheskom vuze" ["Management of foreign student's social adaptation in the Russian technical university"] the $\mathrm{PhD}$ dissertation in sociological sciences, Moscow, 2003, 195 p.

[6] A. Shevchenko, I. Soboleva, "Adaptaciya inostrannyh studentov problemy i vozmozhnye puti ih resheniya" ["Adaptation of foreign students: problems and possible solutions"], Problems and prospects for the development of education in Russia, 2012, Vol. 16, [Electronic resource] Access mode: http://cyberleninka.ru/article/n/adaptatsiyainostrannyh-studentov-problemy-i-vozmozhnye-puti-ih-resheniya

[7] A. Kormilicyn "Upravlenie processom adaptacii inostrannyh studentov v novyh ehkonomicheskih usloviyah" ["Managing the process of adaptation of foreign students in the new economic conditions"], proceedings of International Scientific and Technical Conference "Modern scientific and technical problems of civil aviation". Moscow, 1996, pp.258.

[8] E. Yakubenko, N. Zajceva, "Osobennosti pedagogicheskogo obshcheniya na ehtape adaptacii inostrannyh studentov $\mathrm{k}$ obucheniyu $\mathrm{v}$ Rossijskom VUZe" ["Peculiarities of pedagogical communication at the stage of adaptation of foreign students to study in the Russian Higher Educational Institution"], [Electronic resource] Access mode: http://rep.polessu.by/bitstream/112/8188/1/12.pdf

[9] O. Fisochenko, A. Polikarpova, "Razrabotka kompleksnogo podhoda k upravleniyu adaptaciej inostrannyh studentov" ["Development of a comprehensive approach to managing the adaptation of foreign 
students"], In the world of scientific discoveries, 2015, Vol. 9.2 (69), pp. 705-712

[10] E. Fantalova "Uroven sootnosheniya cennosti i dostupnosti v razlichnyh zhiznennyh sferah psihometricheskoe issledovanie pokazatelej. Metodika" ["The level of correlation of "value"and "accessibility" in various life spheres: psychometric study of indicators. Methodology"], The World of Psychology, Moscow, 2011, Vol. 2 (66), pp. 228-243.

[11] O. Fedorova, E. Podkorytova, T. Burgardt, "Ehkzogennye i ehndogennye faktory vliyayushchie na vnutrennyuyu sinhronizaciyu sutochnyh ritmov vegetativnyh funkcij cheloveka v obychnyh i subehkstremalnyh usloviyah sredy" ["Exogenous and endogenous factors influencing the internal synchronization of diurnal rhythms of the vegetative functions in the ordinary and subextremal conditions of the environment"], Human Physiology, 2009, T. 35, Vol.2, pp. 96-102.

[12] O. Fisochenko, E. Berestneva, O. Zharkova, "Opredelenie informativnosti psihologicheskih pokazatelej $\mathrm{v}$ zadachah ocenki adaptacii inostrannyh studentov" ["Determining the informative value of psychological indicators in the problems of assessing the foreign student's adaptation"], Information technology in science, education and management: materials of the XLIV International Conference and the XIV International Conference of Young Scientists proceedings, Moscow, 2016, pp. 160-163.

[13] L. Ancyferova "Lichnost $\mathrm{v}$ trudnyh zhiznennyh usloviyah pereosmyslivanie preobrazovanie situacij i psihologicheskaya zashchita" ["Personality in difficult living conditions: re-comprehension, transformation of situations and psychological defense" ], Psychological journal , 1997, T. 15, vol.3, pp. 131-134

[14] E. Gubler "Vychislitelnye metody analiza i raspoznavaniya patologicheskih processov" ["Computational methods of analysis and recognition of pathological processes"], Leningrad: Medicine, 1978, 296 p.

[15] O. Berestneva, O. Maruhina, D. Shcherbakov, "Problema adaptacii inostrannyh studentov kak problema adaptacii subekta deyatelnosti $\mathrm{k}$ izmenennym usloviyam" ["The problem of adaptation of foreign students as a problem of adaptation of the subject of activity to changed conditions"], Russia, Publishing House "Academy of Natural History", 2013.

[16] O. Fisochenko, "Ispolzovanie metoda nechetkoj klassifikacii dlya resheniya zadachi diagnostiki urovnya adaptacii inostrannyh studentov obuchayushchihsya v rossijskih vuzah" ["Using the fuzzy classification method for solving the problem of diagnosing the level of adaptation of foreign students studying in Russian universities"], Theoretical and applied aspects of modern science: IV international correspondence scientific-practical conference on all branches of scientific knowledge proceedings, Belgorod, 2014, pp. 198-201.

[17] O. Fisochenko, E. Lyahova, "Postroenie proforientacionnoj modeli na osnove diskriminantnogo analiza" ["Construction of professional orientation model based on discriminant analysis"], Modern problems of science and education , 2013, vol. 6, [Electronic resource] Access mode: www.science-education.ru/113-10790 